\title{
In vitro evaluation of filling of lateral root canals with different filling materials by using digital radiography
}

\author{
Avaliação in vitro da obturação de canais laterais com diferentes \\ materiais obturadores utilizando radiografia digital
}

\begin{abstract}
Purpose: To evaluate the ability of different endodontic systems to fill simulated lateral canals using resources of digital radiography.

Methods: Seventy extracted single-rooted human teeth were selected, the coronal access was performed, and the working length was established $1 \mathrm{~mm}$ short of the foramen. Two lateral canals were created, one in the middle third and one at the apical third, in each root canal. After chemo-mechanical preparation the teeth were divided into 7 groups $(n=10)$ according to the filling material used: G1 Epiphany, G2 AH Plus, G3 EndoRez, G4 EndoFill, G5 Endomethasone, G6 Sealapex and G7 Sealer 26. In the G1 Epiphany system, Resilon cones were used. In all other groups gutta-percha cones were used. After seven days of storage, digital radiographs were taken to assess the results. The program DBSWIN measured the total length, in $\mathrm{mm}$, of each lateral canal and the length, in $\mathrm{mm}$, that each filling system was able to obturate the canals. Data were analyzed by ANOVA and Tukey's test at the $5 \%$ significance level.

Results: The filling system Sealer 26/gutta-percha showed less capacity to fill lateral canals than the other filling systems tested $(P<0.05)$; statistical analysis revealed no statistically significant difference in the ability to fill lateral canals between the other groups $(P>0.05)$.

Conclusion: The system Sealer 26/gutta-percha was less effective in the filling of simulated lateral canals.
\end{abstract}

Key words: Filling; filling materials; lateral canals

\section{Resumo}

Objetivo: Avaliar a capacidade de obturação de canais laterais de diferentes sistemas obturadores endodônticos por meio de radiografia digital.

Metodologia: Setenta dentes humanos unirradiculares extraídos foram selecionados, a abertura coronária foi feita e o comprimento de trabalho foi determinado $1 \mathrm{~mm}$ aquém do forame apical. Foram confeccionados dois canais laterais, um no terço médio e outro no terço apical, em cada canal radicular. Após o preparo químico-mecânico os dentes foram divididos em 7 grupos $(n=10)$ de acordo com o material obturador utilizado: $G 1$, Epiphany; $G 2, A H$ Plus; G3, EndoRez; G4, EndoFill; G5, Endomethasone; G6, Sealapex; G7, Sealer 26. No G1 foram utilizados cones de Resilon e nos demais grupos cones de guta-percha. Sete dias após a obturação foram feitas radiografias digitais e as imagens foram introduzidas num software para a leitura dos resultados. Para avaliar a obturação dos canais laterais, o software mensurou em $\mathrm{mm}$ a extensão total de cada canal lateral e o quanto em $\mathrm{mm}$ cada sistema obturador conseguiu preencher em cada um deles. Os dados foram analisados estaticamente por ANOVA e teste de Tukey ao nível de significância de $5 \%$.

Resultados: O sistema obturador Sealer 26/guta-percha obturou uma menor quantidade de canais laterais comparado aos demais sistemas obturadores em uma diferença estatisticamente significante $(P<0,05)$; não houve diferença estatisticamente significante entre os demais grupos $(P>0,05)$.

Conclusão: $\bigcirc$ sistema obturador Sealer 26/guta-percha apresentou uma menor efetividade na obturação de canais laterais simulados.

Palavras-chave: Obturação; materiais obturadores; canais laterais

\author{
Matheus Albino Souza a \\ Doglas Cecchin b \\ Ana Paula Farina ${ }^{b}$ \\ Marcio Luiz Fonseca Menin c \\ Alexandre Correa Ghisi ${ }^{\circ}$ \\ Joao Vicente Baroni Barbizam ${ }^{b}$
}

- School of Dental Medicine, Tufts University, Boston, MA, United States

b University of Passo Fundo, Passo Fundo, RS, Brazil

c Pontifical Catholic University of Rio Grande do Sul, Porto Alegre, RS, Brazil

Correspondence:

Matheus Albino Souza

Boylston Street, $1167 / 22$

Boston, MA - United States

02215

E-mail:matheus292@yahoo.com.br

Received: December 14, 2011

Accepted: January 26, 2012

Conflict of Interests: The authors state that there are no financial and personal conflicts of interest that could have inappropriately influenced their work.

Copyright: (C) 2011 Souza et al. : licensee EDIPUCRS This is an Open Access article distributed under the terms of the Creative Commons AttributionNoncommercial-No Derivative Works 3.0 Unported License. 


\section{Introduction}

The threedimensional obturation of the root canal system is extremely important, as it could prevent reinfection (1) and isolate microorganisms in inaccessible areas, without access to space and nutrients (2). The difficulty to fill adequately the root canal system is ascribed to its anatomical complexity and peculiar morphological configuration, which includes multiple foraminas, apical deltas, accessory and lateral root canals (3). Therefore, the overall success of an endodontic treatment is closely related to the filling materials and techniques utilized (4-6).

Filling of the root canal system is usually performed using a combination of sealer and gutta-percha. Gutta-percha is widely used due to satisfactory physical and biological properties (7). However, the lack of adherence of gutta-percha to both the canal walls and cement is a major disadvantage. As a result, sealer must be used to establish intimate adaptation of the gutta-percha to the dentinal walls (8).

Endodontic filling materials of all types must meet certain requirements to be considered adequate. Flow is an important property because it represents the ability to penetrate small irregularities on the interior surface of the root canal system and dentinal tubules $(9,10)$. Moreover, the flow of filling material in these regions can assist in the disinfection process $(11,12)$. Lateral, secondary, and accessory canals may provide a physical pathway between the main canal and the periodontal ligament, as well as the apical foramen. These connections can allow the passage of bacteria and tissue breakdown products (13) and their presence may be related to the process of infection and necrosis of the root canal (14).

Several in vitro models have been proposed to evaluate the ability to fill lateral canals of endodontic filling systems. Some studies have suggested creating simulated lateral canals in resin blocks (15-17) and creating lateral canals with hand files, type-K $\# 15$, coupled to a low speed motor $(3,18)$. Clearing $(19)$ and conventional radiographs $(18)$ have been used to measure the results of samples prepared in these models. At the same time, light microscopy with digital image processing (20) and confocal laser scanning microscopy (21) were used to evaluate depth and percentage of penetration of endodontic sealers into dentinal tubules. However, these models do not accurately represent the clinical and anatomic features of the tooth, in vivo. Thus, the evaluation methods may not be sufficiently accurate to carry out the measurements.

The aim of this study was to evaluate, in vitro, the ability to fill simulated lateral canals of seven different systems of endodontic filling material in extracted human teeth as measured by software quantitative analysis of digital radiographs.

\section{Materials and methods}

Seventy extracted maxillary central incisors were used for this study after approval of the Ethics Committee of the School of Dentistry of University of Passo Fundo, Brazil. The coronal portion of the teeth was removed using a diamond disc at low speed under irrigation and a standard length of $15 \mathrm{~mm}$ was achieved for each sample.

Two lateral canals, one in the middle third and one at apical third, were prepared perpendicular to the longitudinal axis of each sample using a cylindrical drill of $0.10 \mathrm{~mm}$ (Union Tool Europe SA, Marin, Neuchâtel, Switzerland) on a machining center to create the perforations. The penetration of the drill into the root canal was checked by introducing a K-type file number 06 (Dentsply Maillefer, Ballaigues, Switzerland) into the holes created.

The coronal and middle thirds of root canals were prepared with Gates-Glidden burs \#3 and \#2 (Dentsply Maillefer). The working length was established by subtracting $1 \mathrm{~mm}$ from the measurement obtained by placing a K-type file number 10 (Dentsply Maillefer) inside the root canal until the tip could be seen at the foramen. The canals were instrumented up to a size \#45 (Dentsply-Maillefer) by the manual instrumentation through step-back preparation. After every change of drill or file, the canals were irrigated with $2 \mathrm{~mL}$ of $2.5 \%$ sodium hypochlorite. After chemo-mechanical preparation, $3 \mathrm{~mL} \mathrm{17 \%}$ EDTA were used to remove the smear layer. A final wash with $5 \mathrm{~mL}$ of saline solution was administered. The canals were dried with absorbent paper points, concluding the protocol.

Before the filling of root canals, the samples were mounted in blocks of alginate (Dentsply, Petrópolis, RJ, Brazil) to confine the sealer after their flow through the lateral canals in an attempt to simulate the periodontal ligament. The samples were then randomly divided into seven groups $(n=10)$ according to the endodontic filling system used: Group 1 - Resilon/Epiphany, Group 2 - guttapercha/AH Plus, Group 3 - gutta-percha/EndoRez and Group 4 - gutta-percha/Endofill, Group 5 - gutta-percha/ Endomethasone, Group 6 - gutta-percha/Sealapex and Group $7-26$ gutta-percha/Sealer. In all groups the sealer was introduced into the root canal with the aid of a spiral Lentulo number 40 (Dentsply Maillefer) and the filling was done by lateral condensation. For this procedure, the master cone, coated with sealer, was fitted inside the root canal. Lateral condensation was performed with digital spacers 25 and 30 (Dentsply Maillefer) and accessory cones B7/B8 (Tanari, Manaus, AM, Brazil) were introduced to complete the filling. Excess gutta-percha was removed with a heated instrument and cold pluggers were used to condense vertically the gutta-percha. In group 1, an absorbent paper cone coated with primer was introduced into the root canal at the working length prior to completion of lateral condensation, promoted with Resilon cones and Epiphany sealer. After applying the primer and before the removal of excess filling material, the samples were photoactivated for thirty seconds. After being filled, all groups were stored for 48 hours in high humidity at a temperature of $37^{\circ} \mathrm{C}$ to allow the sealers to set.

After 48 hours, the alginate blocks were removed and digital radiographs were made using digital $\mathrm{x}$-ray Spectro 
70x (Dabi Atlante, Ribeirão Preto, SP, Brazil) at 70kVp, $10 \mathrm{~mA}$ and 0.20 seconds of exposure time, at a focal length $30 \mathrm{~cm}$. A positioner was used to maintain a radiation pattern perpendicular to the long axis of the tooth. The processing was developed in the automatic processing machine VistaScan (Dürr Dental, Bietigheim, Deutschland) and the radiographic images obtained were entered into the software program DBSWIN (Dürr Dental, Bietigheim, Deutschland) to read the results through quantitative analysis.

To evaluate the filling of lateral canals, scanned images of each sample were analyzed at $100 \%$ magnification for the total length of each lateral canal and its respective fill with the root canal sealer, in mm (Fig. 1A and B). These measurements were converted to percentage of lateral canal filled, allowing comparison of filling capacity among the different filling systems.

Data were statistically analyzed using analysis of variance (ANOVA) and Tukey's test at a significance level of $5 \%$.
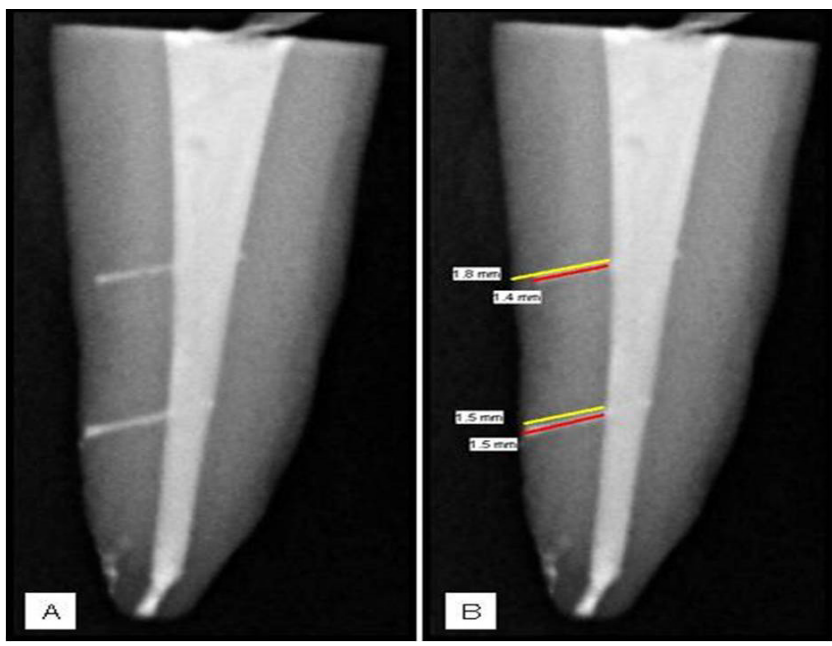

Fig. 1. (A) Digital radiography of the obturated main canal and simulated lateral canals; (B) measurements of the total length $(\mathrm{mm})$ of the lateral canal and the length reached by the sealer (yellow and red lines, respectively).

\section{Results}

Descriptive statistics of the measurements of the lateral canals filling are presented in Table 1. No statistically significant difference in the ability to fill lateral canals was found in both the middle and apical thirds among the filling systems Epiphany/Resilon, AH Plus/gutta-percha, EndoRez/ gutta-percha, Endofill/gutta-percha, Endomethasone/guttapercha and Sealapex/gutta-percha $(P>0.05)$. The filling system Sealer 26/gutta-percha showed less capacity to fill lateral canals, both in the middle and apical thirds, than the other filling systems tested $(P<0.05)$.

\section{Discussion}

When considering the various properties of a root canal filling material which make a material appropriate, proper flow and ability to fill lateral canals have significant importance. The flow is important as it represents the ability to penetrate the small irregularities of the root canal system $(9,10)$ such as the lateral canals.

Several models have been proposed to assess the ability of different endodontic filling materials to fill lateral canals. This study used artificially created lateral canals in human teeth, as proposed by previous study $(19,22)$. Lateral canals were created along different thirds of the root structure using a cylindrical drill of $0.10 \mathrm{~mm}$, checking the penetration of the drill and introducing a k-type manual file number 06 in the perforation created. Similar models have been proposed creating lateral canals with hand files, type-K \#15, coupled to a low speed motor $(3,18)$. However, previous studies show that $70.1 \%$ of the branches found in the central incisors have a diameter of less than that of a manual type-k file \# 10 (23). The model proposed by our study is closer to the anatomy of the root canal system found in vivo.

Previous studies have used a limited number of filling system to evaluate the filling effectiveness of simulated lateral canals $(18,19)$. This study proposes the introduction of a higher number of filling materials, promoting an adequate comparison between the systems to evaluate the filling ability of each one, bringing alternatives for this important stage of root canal treatment.

Table 1. Mean*, standard deviation, minimum and maximum of filling percentages (\%) for each experimental group.

\begin{tabular}{lcccc}
\hline \multicolumn{1}{c}{ Groups } & \multicolumn{2}{c}{ Middle third } & \multicolumn{2}{c}{ Apical third } \\
\hline \multicolumn{1}{c}{$\begin{array}{c}\text { Mean, standard } \\
\text { deviation }\end{array}$} & $\begin{array}{c}\text { minimum and } \\
\text { maximum }\end{array}$ & $\begin{array}{c}\text { Mean, standard } \\
\text { deviation }\end{array}$ & $\begin{array}{c}\text { minimum and } \\
\text { maximum }\end{array}$ \\
\hline Epiphany and Resilon & $87.7 \pm 18.51^{a}$ & $55-100$ & $83.10 \pm 30.35^{a}$ & $0-100$ \\
AH Plus and gutta-percha & $83.6 \pm 19.63^{a}$ & $50-100$ & $87.6 \pm 21.61^{a}$ & $33-100$ \\
EndoRez and gutta-percha & $82.60 \pm 23.94^{a}$ & $25-100$ & $80.8 \pm 27.51^{a}$ & $12-100$ \\
EndoFill and gutta-percha & $76.4 \pm 26.85^{a}$ & $16-100$ & $74.6 \pm 25.90^{a}$ & $37-100$ \\
Endomethasone and gutta- & $90.60 \pm 12.86^{a}$ & $70-100$ & $92.60 \pm 13.45^{a}$ & $61-100$ \\
percha & $86.40 \pm 17.79^{a}$ & $43-100$ & $92.60 \pm 13.45^{a}$ & $60-100$ \\
Sealapex and gutta-percha & $19.20 \pm 31.24^{\mathrm{b}}$ & $0-70$ & $34.4 \pm 39.14^{\mathrm{b}}$ & $0-92$ \\
Sealer 26 and gutta-percha & & & &
\end{tabular}

\footnotetext{
* Mean followed by the same letters show no statistical difference
} 
Features such as clearing (19) and conventional radiographs (18), as well as light microscopy with digital image processing (20) and confocal laser scanning microscopy (21) were used to evaluate depth and percentage of penetration of endodontic filling materials into dentinal tubules. The present study used images from digital radiographs and measured the total length of each lateral canal and its respective fill, in $\mathrm{mm}$, using the software DBSWIN. These measurements were converted to percentage of lateral canal filled, allowing a more precise and quantitative comparison of the filling of lateral canals among the different systems of endodontic filling material, similar to that used by previous study (19). Furthermore, digital x-ray software simulates the naturally occurring conditions, position and adaptation of filling systems into the root canal.

The results of this study showed that the filling system Sealer 26/gutta-percha showed a lower ability to fill lateral canals, in both the middle and apical thirds, compared to the other filling systems filling tested. These findings are similar to the findings of previous study, which evaluated the ability of a silicone-based sealer (RoekoSeal) to fill simulated lateral canals, compared to a zinc oxide and eugenol based sealer (Grossman) and a resin sealer (Sealer 26) (18). That study found that sealer Sealer 26 showed the lowest ability to fill lateral canals in the different thirds of the root canal. This finding can be explained by the low flow of the sealer, Sealer 26, detected in a previous study, which evaluated the antimicrobial activity and the rate of flow of different sealers (24). This study found that the endodontic sealer Sealer 26 showed a flow rate significantly lower than that found in root canal sealers AH Plus and Kerr Pulp Canal Sealer.

\section{Conclusions}

Within the limitations of this study, the results suggest that the filling system composed of the resin cement Sealer 26 and gutta-percha was less effective to fill the simulated lateral root canals.

\section{Acknowledgements}

The authors are thankful to Ms. Jaclyn Pak for her assistance with the manuscript.

\section{References}

from canals of root-filled teeth with periapical lesions. Int Endod J 2003;36:1-11.

2. Vivacqua-Gomes N, Gurgel-Filho ED, Gomes BP, Ferraz CC, Zaia AA, Souza-Filho FJ. Recovery of Enterococcus faecalis after single or multiple-visit root canal treatment carried out in infected teeth ex vivo. Int Endod J 2005;38:697-704.

3. Goldberg F, Artaza LP, De Silvio A. Effectiveness of different obturation techniques in the filling of simulated lateral canals. J Endod $2001 ; 27: 362-4$.

4. Facer SR, Walton RE. Intracanal distribution patterns of sealers after lateral condensation. J Endod. 2003;29:832-4.

5. Imai Y, Komabayashi T. Properties of a new injectable type of root canal filling resin with adhesiveness to dentin. J Endod. 2003;29:20-3.

6. Vizgirda PJ, Liewehr FR, Patton WR, Mcpherson JC, Buxton TB. A comparison of laterally condensed gutta-percha, thermoplasticized gutta-percha, and mineral trioxide aggregate as root canal filling materials. J Endod. 2004;30:103-6.

7. Pascon EA, Spangberg LS. In vitro citotoxicity of root canal filling materials: 1. Gutta-Percha J Endod 1990;16:429-33.

8. Gambarini G, Tagger M. Sealing ability of a new hydroxyapatite-containing endodontic sealer using lateral condensation and thermatic compaction of gutta-percha, in vitro. J Endod 1996;22:165-7.

9. Siqueira-Júnior JF, Fraga RC, Garcia PF. Evaluation of sealing ability, pH and flow rate of three calcium hydroxide-based sealers. Endod Dent Traumatol 1995;1 1:225-8.

10. Weis MV, Parashos $\mathrm{P}$, Messer HH. Effect of obturation technique on sealer cement thickness and dentinal tubule penetration. Int Endod J 2004;37:653-63.

11. Siqueira-Júnior JF, Rôças IN, Favieri A, Abad EC, Castro AJ, Gahyva SM. Bacterial leakage in coronally unsealed root canals obturated with 3 different techniques. Oral Surg Oral Med Oral Pathol Oral Radiol Endod 2000;90:647-50.

12. Saleh IM, Ruyter IE, Haapasalo M, Orstavik D. Survival of Enterococcus faecalis in infected dentinal tubules after root canal filling with different root canal sealers in vitro. Int Endod J 2004;37:193-8.

13. De Deus QD. Frequency, location and direction of the lateral, secondary and accessory canals. J Endod 1975;1:361-6.

14. Barkhordar RA, Stewart GG. The potential of periodontal pocket formation associated with untreated accessory canals. Oral Surg Oral Med Oral Pathol 1990;70:769-72.

15. Wolcott J, Himel VT, Powell W, Penney J. Effect of two obturation techniques on the filling of lateral canals and the main canal. J Endod 1997;23:632-5. 
16. DuLac KA, Nielsen CJ, Tomazic TJ, Ferrillo PJ, Hatton JF. Comparison of the obturation of lateral canals by six techniques. J Endod 1999;25:376-80.

17. Silver GK, Love RM, Purton DG. Comparison of two vertical condensation obturation techniques: Toch'n Heat modified and System-B. Int Endod J 1999;32:287-95.

18. Barbizam JV, Souza M, Cecchin D, Dabbel J. Effectiveness of a silicon-based root canal sealer for filling of simulated lateral canals. Braz Dent J 2007;18:20-3.

19. Almeida JF, Gomes BP, Ferraz CC, Souza-Filho FJ, Zaia AA. Filling of artificial lateral canals and microleakage and flow of five endodontic sealers. Int Endod J 2007;40:692-9.

20. De Deus GA, Gurgel-Filho ED, Maniglia-Ferreira C, Coutinho-Filho T. The influence of filling technique on depth of tubule penetration by root canal sealer: a study using light microscopy and digital image processing. Aust Endod J 2004;30:23-8.

21. Ordinola-Zapata R, Bramante CM, Graeff MS, del Carpio Perochena A, Vivan RR, Camargo EJ, Garcia RB, Bernardineli N, Gutmann JL, de Moraes IG. Depth and percentage of penetration of endodontic sealers into dentinal tubules after root canal obturation using a lateral compaction technique: a confocal laser scanning microscopy study. Oral Surg Oral Med Oral Pathol Oral Radiol Endod. 2009;108:450-7.

22. Moretti AG, Pantoja CA, Moreira DM, Zaia AA, Almeida JF. Effect of the smear layer on the filling of artificial lateral canals and microleakage. Braz J Oral Sci $2011 ; 10: 55-9$.

23. Kasahara E, Yasuda E, Yamamoto A, Anzai M. Root canal system of the maxilary central incisor. J Endod 1990;16:158-61.

24. Siqueira-Júnior JF, Favieri A, Gahyva SM, Moraes SR, Lima HC, Lopes HP. Antimicrobial activity and flow rate of newer and established root canal sealers. J Endod 2000;26:274-7. 